\title{
ADVERTISING, RESEARCH AND DEVELOPMENT, AND CAPITAL MARKET RISK: HIGHER RISK FIRMS VERSUS LOWER RISK FIRMS
}

\author{
Miao-Ling Chen ${ }^{1}$, Chi-Lu Peng ${ }^{2}$, An-Pin Wei ${ }^{3}$ \\ ${ }^{1,3}$ Department of Finance, National Sun Yat-sen University, \\ 70 Lien-hai Rd., Kaohsiung 804, Taiwan (R.O.C.) \\ ${ }^{2}$ Department of Finance, Chung Hua University, 707, Sec. 2, \\ Wu Fu Rd., Hsin Chu 300, Taiwan (R.O.C.) \\ E-mails: ${ }^{1}$ miaoling@mail.nsysu.edu.tw; ${ }^{2}$ chilupeng@gmail.com (corresponding author); \\ 3anpinwei@gmail.com
}

Received 01 February 2011; accepted 13 February 2012

\begin{abstract}
This study examines how a firm's advertising and R\&D affects the firm's $\beta$-risk and idiosyncratic risk, which are metrics of interest to both finance executives and senior management. Due to the existence of a non-normal and heteroscedasticity dataset, we use quantile regression to analyze the sample to understand the full behavior of our non-normally distributed datapoints. The evidence of this study shows that: (1) Advertising is significantly associated with lower $\beta$-risk for firms with lower, median and higher $\beta$-risk. (2) R\&D significantly increases $\beta$-risk for firms with median and higher $\beta$-risk firms. (3) Advertising is significantly associated with lower idiosyncratic risk for firms with higher idiosyncratic risk. (4) R\&D is significantly associated with higher idiosyncratic risk for firms with median and higher idiosyncratic risk. In summary, our evidence shows that both advertising and R\&D have a stronger effect on firms with higher $\beta$ - and idiosyncratic risk than on those with lower $\beta$ - and idiosyncratic risk, respectively. Our findings are useful to help both management executives and investors. Firm managers can allocate limited resources more efficiently to reduce their firm risk; investors could exert their influence on firm's senior executives to make decisions that are beneficial to stock returns.
\end{abstract}

Keywords: $\beta$-risk, idiosyncratic risk, advertising, marketing, $R \& D$, quantile regression, CAPM.

Reference to this paper should be made as follows: Chen, M.-L.; Peng, C.-L.; Wei, A.-P. 2012. Advertising, research and development, and capital market risk: higher risk firms versus lower risk firms, Journal of Business Economics and Management 13(4): 724-744.

JEL Classification: M37, G32, C21.

\section{Introduction}

Classical financial theory argues that investors, who make their investment decisions according to the expected utility function, will tend to optimize their risk-reward tradeoff, leading to an equilibrium in which the cross-sectional expected asset returns depend only on the cross-section systematic risks (hereinafter, $\beta$-risk). However, recent litera- 
ture (Lui et al. 2007) considers that $\beta$-risk may not account for sufficient explanatory power of the variation in a stock returns because the residuals of the Capital Assets Pricing Model (CAPM) are influenced by these other sources of covariance (Rosenberg 1974), referred to as non-systematic risk (hereinafter, idiosyncratic risk) ${ }^{1}$. Ang et al. (2006) find that stocks with high idiosyncratic volatility have low average returns. The above evidence implies that investors should be concerned about risks both from the market returns and from changes in firm's individual intrinsic risk. Therefore, the issue of investigating the components of firm's $\beta$-risk and idiosyncratic risk has became a very popular issue among both academics (Ang et al. 2006; Chang, Dong 2006) and practitioners (Lui et al. 2007). For example, Chen (2002) and Ang et al. (2006) show evidence that a firm with higher $\beta$-risk has a lower expected return because investors' prospects for the uncertainty of market returns is increased. Lui et al. (2007) indicate that financial analysts have viewed a firm's idiosyncratic risk as an important measure when issuing their rating for the risk of investing in a stock. Without decomposing a firm's total risk into $\beta$-risk and idiosyncratic risk, management executives and market participants will not understand how or even whether the operating strategies or components efficiently influence a firm's stock returns risk because a firm's $\beta$-risk and idiosyncratic risk may be driven by different reasons.

There is considerable literature in financial studies presenting significantly evidence that the impact of changes in accounting variables such as firm's sales growth can affect a firm's $\beta$-risk and idiosyncratic risk ${ }^{2}$. Recent marketing studies (Fornell et al. 2006; Singh et al. 2005) show that firms with greater intangible market-based assets will have lower firm returns risk. A firm's returns risk could be decomposed into $\beta$-risk and idiosyncratic risk. Regarding $\beta$-risk, this study infers that advertising will create intangible market-based assets such as consumer loyalty, which may lead investors to hold their stocks longer (Goetzmann, Peles 1997), and will lower a firm's stock volatilities from market movements, which has a significant negative impact on firm's $\beta$-risk. With respect to idiosyncratic risk, or the intrinsic risk that cannot be explained by market movements, investing in intangible market-based assets such as advertising may increase product market demand that stabilizes a firm's operating cash flows, and lowers a firm's idiosyncratic risk. With respect to the relation between R\&D and returns risk, Ho et al. (2004) find a significant positive relation between research and development expenditures (R\&D) and $\beta$-risk, while Xu and Zhang (2004) find a significant positive

\footnotetext{
${ }^{1}$ Some studies conclude that $\beta$-risk fails to describe expected stock returns because the market portfolios, such as S\&P 500, NYSE and CRSP index returns, used by prior studies as proxy for market return are not sufficient (Roll 1977; Roll, Ross 1994). That is, residuals of the CAPM model are influenced by these other sources of covariance, referred to as idiosyncratic risk in our study.

${ }^{2}$ Numerous empirical studies have attempted to use accounting variables to explain the level of $\beta$-risk. For example, Beaver et al. (1970) suggested that greater $\beta$-risk is related to certain variables, including higher growth, greater leverage, lower liquidity, smaller asset size, lower dividend payout, and higher levels of earnings variability.
} 
relation between $\mathrm{R} \& \mathrm{D}$ and total risk. ${ }^{3}$ This is because firms may increase the level of uncertainty in their future cash flows by their expenditures on R\&D (McAlister et al. 2007). This decreases the predictability of a firm's future income streams (Kothari et al. 2002), which in turn, increases an individual firm's risk. Instead, past research pays less attention to whether changes in a firm's intangible investment, such as advertising and R\&D, simultaneously both affects both a firm's $\beta$-risk and idiosyncratic risk, which should be a metric of interest to both finance executives and investors ${ }^{4}$. The first goal of this paper is to examine the impact of a firm's advertising and R\&D on both dimensions of stock returns risk: $\beta$-risk and idiosyncratic risk.

Recent studies, Gupta and Liang (2005), Dzikevičius (2005) and Patton (2009) show that the distribution of firm's returns risk is non-normal, with characteristics such as fat tails, excess kurtosis, and skewness or heteroscedasticity. If the empirical dataset exhibits a high degree of non-normality, the estimators using classical mean regression methods and similar methods, offering only a conditional mean or median view of this causal relationship based on the assumption of Gaussian distributed error terms, may driven by a few outliers. Thus these estimators will generate inadequate estimates, omit some important information (Barnes, Hughes 2002) and may lead to inefficient management decisions. For example, when a firm's stock returns risk has a higher volatility level, based on the findings of McAlister et al. (2007), firm executives can spend more in intangible market-based assets to reduce the firm's risk by insulating it from the impact of stock market movements. To the contrary, for firms with lower risk, spending in intangible market-based assets may not have a significant effect on a firm's risk, so firm executives may adjust their budgets to allocate their limited resources on capital expenditures to improve its future cash flows. We argue that the effects of advertising and R\&D may not be constant across different risk levels, especially between the median and the tails of distribution (extremely higher or lower returns risk). With non-normally distributed datasets, Patton (2009) supports the contention that quantile regression is an appropriate method to test for the influence of the independent variable on a quantile of the firm's risk distribution. To mitigate bias from a non-normal sample, this study employs a quantile regression approach ${ }^{5}$. To our knowledge, this is the first study to examine advertising's effects on a firm's $\beta$-risk and idiosyncratic risk by using quantile regression.

The second goal of this paper is to examine the impact of firm's advertising and R\&D expenditures across upper quantile firm risks and lower quantile firm risks. Following

\footnotetext{
${ }^{3}$ No conclusive evidence on this issue of $R \& D$ and $\beta$-risk has yet been produced. For example, McAlister et al. (2007) find that a firm's R\&D creates intangible market-based assets and show that, on average, higher expenditures for a firm's advertising and R\&D could lower the firm's $\beta$-risk. However, most R\&D research (e.g., Ho et al. 2004) supports a positive relationship between R\&D and a firm's risk.

${ }^{4}$ Tuli and Bharadwaj (2009) use a firm's customer satisfaction score as a proxy for a firm's intangible market-based assets and find a negative relationship between customer satisfaction and idiosyncratic risk. The data collection of customer satisfaction scores from the website of American Customer Satisfaction Index (ACSI) is easily accessed but offers a relatively small number of firms.

${ }^{5}$ The residual distribution is asymmetric and varies with independent variable.
} 
Barnes and Hughes (2002), Landajo et al. (2008) and Chen et al. (2010), estimated coefficients of lower quantile (quantile order $\theta$ is from 0.1 through 0.3 ), median quantile (quantile order $\theta$ is from 0.4 through 0.6 ) and upper quantile (quantile order $\theta$ is from 0.7 through 0.9 ) can be used to estimate the change in left-tail firm risk distribution (lower-risk firms), near the median firm's risk distribution (median-risk firms), and in the right-tail firm's risk distribution (higher-risk firms), respectively ${ }^{6}$. In summary, we find that, on average, advertising is significantly associated with lower $\beta$-risk and idiosyncratic risk; R\&D is significantly associated with higher $\beta$-risk but has no significant influence on a firm's idiosyncratic risk. With regard to the results of quantile regression, we find that advertising is significantly associated with lower $\beta$-risk for firms with lower and higher $\beta$-risk, but is only significantly associated with lower idiosyncratic risk for firms with higher idiosyncratic risk. With respect to the relation between $R \& D$ and firm risk, our evidence shows that R\&D significantly increases $\beta$-risk for firms with median and higher $\beta$-risk firms, and is significantly associated with higher idiosyncratic risk for firms with median and higher idiosyncratic risk. Moreover, our evidence shows that both advertising and $R \& D$ have a stronger effect on firms with higher $\beta$-risk and idiosyncratic risk than on those with lower $\beta$-risk and idiosyncratic risk, respectively. Our findings are useful for management executives and investors because (1) firm managers can allocate their limited resources more efficiently; (2) through their investments, investors could exert influence on their firm's executives to make decisions that are beneficial to stock returns.

The rest of the paper is organized as follows. The next section presents the literature review and develops our research hypotheses. Section 3 details the quantile regression method and empirical models in this study, while section 4 describes the data. A discussion on the empirical results and managerial implications then follows, and the paper ends with conclusions.

\section{Literature review and hypotheses}

\subsection{Effects of advertising on $\beta$-risk and idiosyncratic risk}

Several studies in finance suggest the existence of investor bias, which leads investors to buy stocks that they are more familiar with. Frieder and Subrahmanyam (2005) find that individuals prefer holding stocks with high recognition and, consequently, greater information precision (advertising plays an information role for a firm's stockholders). This higher liquidity and increased breadth of ownership may help insulate the firm's stock returns from market downturns, thus lowering its $\beta$-risk. In the CAPM, only systematic risk, or $\beta$-risk is relevant in determining an individual firm's returns, is the risk that can be explained by market movements. Recently, scholars (e.g., Singh et al. 2005; Madden et al. 2006; McAlister et al. 2007) have demonstrated a negative relationship

\footnotetext{
${ }^{6}$ Estimated coefficients of extremely-low quantile $(\theta=0.1)$ and extremely-high quantile $(\theta=0.9)$ can be determined as the estimated change in the extreme-left-tail firm risk distribution (extremely-low risk firms) and in the extreme-right-tail distribution (extremely-high risk firms), respectively (see Chen et al. 2010).
} 
between advertising and $\beta$-risk. They indicate that firms with higher advertising may create more intangible based-assets, such as consumer loyalty and brand equity, and thereby enhance the product market demand (Grullon et al. 2004). This can increase sales growth compared to their competitors with lower advertising expenditures, and thereby help insulate those firms from the impact of stock market movements. This current study builds on this literature to propose that advertising lowers a firm's $\beta$-risk. Therefore, we present the following hypothesis.

H1: The higher a firm's advertising, the lower is its $\beta$-risk.

An individual firm's total risk due to stock returns could be decomposed into $\beta$-risk and idiosyncratic risk. But the result of $\beta$-risk is only part of the picture since it accounts for only approximately $20 \%$ of the variation in a firm's stock returns (Tuli, Bharadwaj 2009). Although the idiosyncratic risk can be reduced through diversification with a heterogeneous stock portfolio, firms with higher idiosyncratic risk may put their survival at risk (Clayton et al. 2005), which in turn may affect a firm's stock pricing. Ang et al. (2006) find that high idiosyncratic risk leads to low average returns on stocks. A firm's idiosyncratic risk should thus be of more concern to a firm's senior management, finance executives and market participants.

As mentioned above, idiosyncratic risk accounts for a large part of stock returns volatility, which is affected primarily by a firm's operating activities and strategies. Therefore, firms with higher advertising expenditure may greater stability of revenues in more stable cash flows and thereby lower their idiosyncratic risk (Tuli, Bharadwaj 2009). Thus, the second hypothesis concerning the effects of advertising on idiosyncratic risk is as follows.

H2: The higher a firm's advertising, the lower is its idiosyncratic risk.

\subsection{Effects of $R \& D$ on $\beta$-risk and idiosyncratic risk}

In the existing marketing literature there is increasing evidence for the influence of $R \& D$ on different performance metrics. It is well established that firms' $R \& D$ generates persistent profits (Roberts 2001), high stock returns (Mizik, Jacobson 2003; Chan et al. 2001; Lev, Sougiannis 1996), superior market value (Jaffe 1986; Griliches 1987; Joshi, Hanssens 2004), higher changes in market values (Bublitz, Ettredge 1989; Woolridge 1988; Chan et al. 2001; Austin 1993), and effects to the $\beta$-risk in the stock market (Ho et al. 2004; McAlister et al. 2007). Furthermore, Ho et al. (2004) conclude that, on average, the relation between firm's $\beta$-risk and R\&D intensity is significantly positive, and the study by Berk et al. (2004) also shows that R\&D induces a systematic component of risk. Chan et al. (2001) and Kothari et al. (2002) find that R\&D increases a firm's total risk, the combination of $\beta$-risk and idiosyncratic risk, because R\&D may decrease the predictability of a firm's future income streams. Therefore, we have the following hypothesis.

H3: The higher a firm's $R \& D$, the higher is its $\beta$-risk.

Chambers et al. (2002) find that the excess returns are much more variable over time for R\&D-intensive firms than for firms with little or no R\&D investment, and that both 
analysts' forecasts of future earnings and actual future earnings are unstable for firms with higher R\&D. The market-based assets created by $R \& D$ would increase the uncertainty of future revenue, thereby enhancing the volatility of profit for an individual firm (Kothari et al. 2002). A firm's idiosyncratic risk that cannot be explained by market movements should be driven by a firm's intrinsic components. Thus, a firm's R\&D expenditure may have a powerful effect on its idiosyncratic risk. These effects would increase the firm's idiosyncratic risk, and thus the following hypothesis on the impact of R\&D on idiosyncratic risk is proposed.

H4: The higher a firm's R\&D, the higher is its idiosyncratic risk.

\subsection{Effects of advertising and $R \& D$ on the higher and lower risk firms Quantile regression and least squares approach}

Ordinary Least Squares (OLS), Fixed Effect Models, Hierarchical Linear Regression (HML) and Least Absolute Deviations (LAD) methods are popular methods used in marketing studies. But overall, these methods offer only a conditional mean (median) view of the causal relationship, based on the assumption of Gaussian distributed error terms; that is, these methods are effective for understanding the central tendencies within a normal distributed dataset. However, some researchers have pointed out that if the distribution of causal effects exhibits a high degree of non-normality, fat tails, excess kurtosis and skewness (e.g. Coad, Rao 2006; Lee 2008; Meligkotsidou et al. 2009; Chen et al. 2010) or heteroscedasticity (Landajo et al. 2008; Krasnikov, Jayachandran 2008), the conditional mean effect would not be efficient and may lead to unreliable estimates (Barnes, Hughes 2002). As shown in Table 1 of this study, a firm's $\beta$-risk (idiosyncratic risk) may exhibit a high degree of non-normality using the Jargue-Bera normality tests. The results of Jargue-Bera normality tests are given in the notes to Table 1 . In addition, Panels A and B show that a firm's $\beta$-risk and idiosyncratic risk are skewed and have kurtosis, suggesting that the distribution of firm's $\beta$-risk and idiosyncratic risk are characterized by large skewness, kurtosis, or in general deviations from normality. Due to the phenomenon of non-normal distribution sample data, this study imposes quantile regression on the sample analysis in order to avoid estimation bias.

Quantile regression, introduced by Koenker and Bassett (1978), is an extension of median regression that is based on the minimization of weighted absolute deviations to estimate conditional quantile functions. In contrast to the resulting estimated coefficients from OLS regression, a quantile regression estimator is robust to extreme values (Koenker, Bassett 1978). Koenker and Hallock (2001) note that quantile regression can minimize estimated bias that generated from a skewed sample. This approach has been widely used in many areas of finance such as the investigation of the relation of political cycles and stock market (Santa-Clara, Valkanov 2003), risk management and insurance (Viscusi, Born 2005), capital structure (Fattouh et al. 2005), determinants of housing price (Zietz et al. 2008), equity REIT returns (Chen et al. 2010) and hedge fund returns (Meligkotsidou et al. 2009).

The basic framework of quantile regression is as follows. Considering a standard linear model $\mathbf{y}=\mathbf{x}^{\prime} \boldsymbol{\beta}+\boldsymbol{\varepsilon}$, where $\mathbf{y}=\left(y_{1}, y_{2}, \cdots, y_{n}\right)^{\prime}$ is the vector of dependent variable, with 
the unconditional distribution function $F_{Y}(y)$, the $\theta^{\text {th }}$ quantile of $F_{Y}(y)$ was denoted as $Q_{Y}(\theta) ; \mathbf{x}^{\prime}=\left(x_{1}, x_{2}, \cdots, x_{m}\right)$ is the vector of regressors; $\boldsymbol{\beta}=\left(\beta_{1}, \beta_{2}, \cdots, \beta_{m}\right)^{\prime}$ is the vector of parameters to be estimated; $\boldsymbol{\varepsilon}=\left(\varepsilon_{1}, \cdots, \varepsilon_{n}\right)^{\prime}$ is the vector of residuals. In order to estimate the parameters of our interest, we let $F_{Y}^{-1}(\cdot)$ as $Q_{Y}(\theta)=\inf \left\{y: F_{Y}(y) \geq \theta ; \theta \in(0,1)\right\}$, where $Q_{Y}(\theta)$ is called the unconditional quantile function of $Y$. The condition quantile function of $y$ given $X=x$ has the form $Q_{y_{i} \mid x}\left(\theta_{j} \mid X=x_{i}\right)=\mathbf{x}^{\prime} \boldsymbol{\beta}^{\theta_{j}}, \boldsymbol{\beta}^{\theta_{j}}=\left(\beta_{1}^{\theta_{j}}, \beta_{2}^{\theta_{j}}, \cdots, \beta_{m}^{\theta_{j}}\right)^{\prime}$, where $j=1, \cdots, k$, is the vector of parameters to be estimated, and the quantity $\beta_{i}^{\theta_{j}}$ is called the $j$ th's $\theta$ regression quantile, which can be estimated by solving:

$$
\arg \min _{\boldsymbol{\beta} \in \mathbf{R}^{K}}\left\{\sum_{\left(i: y_{i} \geq \mathbf{x}^{\prime} \boldsymbol{\beta}\right)} \theta\left|y_{i}-\mathbf{x}^{\prime} \boldsymbol{\beta}\right|+\sum_{\left(i: y_{i}<\mathbf{x}^{\prime} \boldsymbol{\beta}\right)}(1-\theta)\left|y_{i}-\mathbf{x}^{\prime} \boldsymbol{\beta}\right|\right\}, \theta \in(0,1) .
$$

Equation (1) could be efficiently solved by linear programming methods (see, Koenker 2000; Coad, Rao 2006; Landajo et al. 2008). In particular, a special case $\theta_{k}=0.5$, which minimizes the sum of absolute residuals, corresponds to median regression. However, in this study, we are not only interested in each single quantile, but also in tracing the entire distribution of the dependent variable (firm's risk) given the covariates (advertising and R\&D). The quantile regression method allows us to acknowledge the heterogeneity on firm's risk (Patton 2009) and consider the possibility that estimated slope parameters vary at different quantiles of the conditional distribution of firm's risk. The testing problem is as follows:

$$
\begin{aligned}
& H_{0}: \beta_{i}^{\theta_{j}}=\cdots=\beta_{k}^{\theta_{k}} \\
& H_{1}: \beta_{i}^{\theta_{j}} \neq \cdots \neq \beta_{i}^{\theta_{k}}
\end{aligned}, \forall i=1, \cdots, n .
$$

Thus, the hypothesis concerning the impacts of advertising and R\&D on the conditionaldistribution of firm's $\beta$-risk and idiosyncratic risk is as follows.

H5: The estimated slope parameters vary at different quantiles of the conditional distribution of firm's $\beta$-risk and idiosyncratic risk.

\section{Research method}

\section{1. $\beta$-risk and idiosyncratic risk measurements}

CAPM was developed by Sharpe (1964), Lintner (1965), and Mossin (1966), and was immediately embraced by the academic community. In CAPM, Sharpe (1964) and Roll (1977) indicate that only $\beta$-risk is relevant in determining an individual security's return. However, CAPM model has received less than full-fledged support in empirical tests (Fama, MacBeth 1973; Rosenberg 1974; Roll 1977; Lui et al. 2007) because residuals of the CAPM model are influenced by other sources of covariance. That is, a stock's risk may include $\beta$-risk and idiosyncratic risk, stock's $\beta$-risk is defined as the stock's return covariance with the market's return while idiosyncratic risk is the risk associated with an individual stock. The specific measure of $\beta$-risk used in CAPM is called an individual stock's beta, $\beta_{i}$, and is defined as the correlation of a stock's 
excess return $\left(E R_{i, t}=R_{i, t}-R_{f, t}\right)$, with the excess return on the market's portfolio $\left(R M F_{t}=R_{m, t}-R_{f, t}\right)$, as specified in following equation:

$$
E R_{i, t}=\alpha_{i, T}+\beta_{i, T} R M F_{t}+\varepsilon_{i, t}, t=0, \ldots, T,
$$

where $\beta_{i, T}$ denotes $\beta$-risk of firm $i$ during time $T$, is the an estimate of the degree of co-movement between a stock's return and the return on the market portfolio; $R_{i, t}$ is the monthly raw return of firm $i$ at time $t ; R_{m, t}$ is the monthly raw return of market portfolio at time $t$; and $R_{f, t}$ is the risk-free rate at time $t$.

As mention above, the total variance of an individual firm's return (total risk) could be decomposed into $\beta$-risk and idiosyncratic risk. $\beta$-risk is an inherently long-term construct that captures the extent to which a firm's stock return covaries with market return (Beaver et al. 1970). Idiosyncratic risk, is the extra volatility of an individual firm's return, the risk that is not captured by $\beta$-risk. Recent studies document that a firm's idiosyncratic risk plays an important role for financial analysts in their rating of the risk for investing in a firm's stock (Lui et al. 2007), and that the relationship between idiosyncratic risk and stock return is negative (Ang et al. 2006). Following McCue and Kling (1994), Chang and Dong (2006) and Ang et al. (2006), in this study, the firm excess returns are regressed against returns from the market excess returns using Equation (3) and the residuals $\left(\varepsilon_{i, t}\right)$ are saved. Then the standard deviation of these residuals $\left(\sqrt{\operatorname{Var}\left(\varepsilon_{i, t}^{2}\right)}\right)$ could be considered as a firm's idiosyncratic risk. When we refer to firm's idiosyncratic risk, we mean idiosyncratic volatility relative to the CAPM model. This paper estimates the firm's $\beta$-risk based on Beaver et al. (1970) and McAlister et al. (2007), using a five-year moving window. This was accomplished by using stock returns for the previous 60 months, relative to the equal-weighted return for the stock market for that period.

\subsection{Models and operational definition of variables}

We use monthly stock data to compute a firm's $\beta$-risk and idiosyncratic risk by using least squares regression equations of the form:

$$
\begin{gathered}
\beta_{i, T}=\alpha+\gamma_{1} A D_{i, T-1}+\gamma_{2} R D_{i, T-1}+\mathbf{C}^{\prime} \boldsymbol{\gamma}+\boldsymbol{\varepsilon}, \\
\sigma_{i, T}^{2}=\chi+\gamma_{1} A D_{i, T-1}+\gamma_{2} R D_{i, T-1}+\mathbf{C}^{\prime} \boldsymbol{\gamma}+\boldsymbol{\delta},
\end{gathered}
$$

where $\beta_{i, T}$ in Equation (4) denotes the average $\beta$-risk of firm $i$ between January of year $t$ and December of year $t+5$. In Equation (5), $\sigma_{i, T}^{2}$ is the idiosyncratic risk of firm $i$ between January of year $t$ and December of year $t+5$.

Following McAlister et al. (2007), we measured advertising and R\&D using the fiveyear moving average advertising expenditure of firm $i$ at the end of year $T$ between year $t$ and year $t+5$ :

$$
\mathrm{AD}_{i, T}=\frac{1}{5} \sum_{t=1}^{5}\left(\mathrm{AD}_{i, t} / \text { Sales }_{i, t}\right),
$$




$$
\mathrm{RD}_{i, T}=\frac{1}{5} \sum_{t=1}^{5}\left(\mathrm{RD}_{i, t} / \text { Sales }_{i, t}\right),
$$

where $\mathrm{AD}_{i, t}$ denotes advertising expenditure of firm $i$ at the end of year $t$; and Sales ${ }_{i, t}$ is the amount of annual sales of is firm $i$ at the end of year $t . \mathrm{RD}_{i, t}$ denotes $\mathrm{R} \& \mathrm{D}$ expenditure of firm $i$ at the end of year $t$.

As mentioned above, Beaver et al. (1970), as well as McAlister et al. (2007) document that greater $\beta$-risk is related to some accounting variables, including: asset growth rate, financial leverage, liquidity, asset size, and competitive intensity. We also included these as the control variables in our $\beta$-risk and idiosyncratic risk model:

We measured asset growth rate, financial leverage, liquidity, and asset size using the five-year moving average asset growth rate, financial leverage, liquidity, and asset size of firm $i$ between year $t$ and year $t+5$ :

$$
\begin{gathered}
G_{i, T}=\frac{1}{5} \ln \left(\sum_{t=1}^{5} \mathrm{TA}_{i, t} / \mathrm{TA}_{i, t=1}\right), \\
\text { Leverage }_{i, T}=\frac{1}{5} \sum_{t=1}^{5}\left(\mathrm{TA}_{i, t} / \mathrm{TD}_{i, t}\right), \\
\text { Liquidity }_{i, T}=\frac{1}{5} \sum_{t=1}^{5}\left(\mathrm{CA}_{i, t} / \mathrm{CL}_{i, t}\right), \\
\mathrm{TA}_{i, T}=\frac{1}{5} \sum_{t=1}^{5} \ln \left(\mathrm{TA}_{i, t}\right),
\end{gathered}
$$

where $\mathrm{TA}_{i, t}$ denotes the total assets of firm $i$ at the end of fiscal year $t . \mathrm{TD}_{i, t}$ denotes the total debt of firm $i$ at the end of fiscal year $t$. $\mathrm{CA}_{i, t}$ denotes the current asset of firm $i$ at the end of fiscal year $t$, and $\mathrm{CL}_{i, t}$ is the current liquidity of firm $i$ at the end of fiscal year $t$.

This study measured the competitive intensity of the firm using Herfindahl's Concentration Index $\left(\mathrm{HHI}_{i, t}\right)$ as a proxy for competitive intensity of firm $i^{7}$ :

$$
\mathrm{HHI}_{i, t}=\sum_{i=1}^{N}\left(\operatorname{Sales}_{i, t} / \sum_{i=1}^{N} \operatorname{Sales}_{i, t}\right)^{2} .
$$

\subsection{Sample description}

The data used to test the hypotheses, including advertising, R\&D expenditures, sales, total assets, total debt, current assets, and current liquidity were obtained from the COMPUSTAT database, including all firms listed on the New York Stock Exchange (NYSE) during the period between January 1981 and December 2007 for which annual advertising spending figures were available. We deleted those samples whose stocks had

\footnotetext{
${ }^{7}$ Two digit Standard Industrial Classification (SIC) codes are used to identify industry groups in order to calculate the HHI. The two-digit SIC groupings are similar to those employed by Boudoukh et al. (1994), Jorion (1991) and Moskowitz and Grinblatt (1999).
} 
been traded on the NYSE for less than 24 months, stocks with negative book-to-market ratio, stock prices below US\$ 2 (Ball et al. 1995; Hertzel et al. 2002), and any missing observations in the data set, to mitigate microstructure effects associated with low-price stocks (Cooper et al. 2004).

Table 1 illustrates two panels of descriptive statistics. In Table 1, Panel A (B) shows that the average value for $\beta$-risk (idiosyncratic risk) for all individual firms is 1.066 (0.013), with an standard deviation of $0.644(0.015)$. The mean value for advertising in the $\beta$-risk (idiosyncratic risk) model is 0.038 (0.039), ranging from $0(0)$ to 0.280 (0.280). The mean value for R\&D in $\beta$-risk (idiosyncratic risk) model is 0.033 (0.033), ranging from $0(0)$ to $0.471(0.471)$. For the control variables in this paper, asset growth

Table 1. Descriptive statistics

Panel A: $\beta$-risk model

\begin{tabular}{lccccccc}
\hline Variables & Mean & SD & Median & Max. & Min. & Kurtosis & Skewness \\
\hline$\beta_{i, T}^{\mathrm{a}}$ & 1.066 & 0.644 & 0.976 & 4.087 & 0.000 & 104.159 & 0.785 \\
\hline $\mathrm{AD}_{i, T-1}$ & 0.038 & 0.042 & 0.023 & 0.280 & 0.000 & 6.855 & 2.253 \\
\hline $\mathrm{RD}_{i, T-1}$ & 0.033 & 0.059 & 0.010 & 0.471 & 0.000 & 14.760 & 3.317 \\
\hline $\mathrm{G}_{i, T}$ & 0.356 & 0.484 & 0.280 & 3.519 & -1.277 & 5.303 & 1.249 \\
\hline Leverage $_{i, T}$ & 1.896 & 4.527 & 0.000 & 44.163 & 0.000 & 24.209 & 4.239 \\
\hline Liquidity $_{i, T}$ & 2.172 & 1.437 & 1.834 & 22.370 & 0.420 & 46.308 & 4.770 \\
\hline $\mathrm{TA}_{i, T}$ & 7.467 & 1.587 & 7.458 & 11.805 & 2.781 & -0.051 & 0.085 \\
\hline $\mathrm{HHI}_{i, t}$ & 0.089 & 0.071 & 0.059 & 0.378 & 0.032 & 3.919 & 2.193 \\
\hline
\end{tabular}

Notes: ${ }^{a}$ Jarque-Bera statistic of the average firm's $\beta$-risk is $233.997(\mathrm{p}$-value $=0.000)$.

Observations $=1354$

Panel B: Idiosyncratic risk model

\begin{tabular}{lccccccc}
\hline Variables & Mean & SD & Median & Max. & Min. & Kurtosis & Skewness \\
\hline$\sigma_{i, T}^{2}{ }^{\mathrm{b}}$ & 0.013 & 0.015 & 0.009 & 0.278 & 0.001 & 74.314 & 7.007 \\
\hline $\mathrm{AD}_{i, T-1}$ & 0.039 & 0.042 & 0.024 & 0.280 & 0.000 & 6.449 & 2.195 \\
\hline $\mathrm{RD}_{i, T-1}$ & 0.033 & 0.058 & 0.011 & 0.471 & 0.000 & 15.104 & 3.347 \\
\hline $\mathrm{G}_{i, T}$ & 0.354 & 0.490 & 0.278 & 3.519 & -1.322 & 5.347 & 1.255 \\
\hline Leverage $_{i, T}$ & 1.853 & 4.468 & 0.000 & 44.163 & 0.000 & 24.954 & 4.296 \\
\hline Liquidity $_{i, T}$ & 2.163 & 1.426 & 1.830 & 22.370 & 0.420 & 46.530 & 4.761 \\
\hline $\mathrm{TA}_{i, T}$ & 7.455 & 1.608 & 7.463 & 11.805 & 2.781 & -0.002 & 0.028 \\
\hline $\mathrm{HHI}_{i, t}$ & 0.089 & 0.071 & 0.060 & 0.378 & 0.032 & 3.789 & 2.167 \\
\hline
\end{tabular}

Notes: bJarque-Bera statistic of the average firm's idiosyncratic risk is 606652. (p-value $=0.000$ ). Observations $=1396$ 
rate, financial leverage liquidity, asset size and the competitive intensity of the firm, the respective means are $0.356(0.354), 1.896(1.853), 2.172(2,163), 7.467(7,455)$ and 0.089 (0.089) in $\beta$-risk (idiosyncratic risk) model, indicating that, on average, the sample firms in this study are stable growth companies with good debt-paying ability and capital structure. Table 1 also shows Jarque-Bera test results, suggesting that a firm's $\beta$-risk and idiosyncratic risk are non-normally distributed ${ }^{8}$. As shown in Panel A (B) of Table 1 , the value of skewness of $\beta$-risk (idiosyncratic risk) is 0.785 (7.007), suggesting that a firm's $\beta$-risk and idiosyncratic risk are skewed. A firm's $\beta$-risk and idiosyncratic risk have large kurtosis, indicating fat tails. For the explanatory variables, Panels A and $\mathrm{B}$ show that the skewness and kurtosis values of advertising, $\mathrm{R} \& \mathrm{D}$ and control variables are skewed and have excess kurtosis.

Panels A and B of Table 2 provide a simple correlation matrix for the variables in $\beta$-risk and idiosyncratic risk models, respectively. Table 2 reports that the largest correlation coefficient is 0.420 , which is lower than 0.7 , Lind et al. (2004) indicate that the regression model should not exhibit the multicollinearity problem when the correlation coefficients between independent variables are lower than 0.7. In Table 2, consistent with the results of correlation coefficients in McAlister et al. (2007), we find that some correlations are significant at $\mathrm{P}<0.01$. Therefore, this study further tests for potential multicollinearity by checking the variance inflation factors (VIFs) in our models. Previous studies state that if any of the VIFs exceed 10 (Montgomery et al. 2001) or the mean VIF is more than 1.9 (Shimizu, Hitt 2005; Adegbesan, Higgins 2010), the associated regression coefficients are poorly estimated because of multicollinearity. However, in our model we find that the largest single VIF is 1.353 in the $\beta$-risk model, and the mean VIF in the $\beta$-risk model and idiosyncratic risk model are about 0.980 and 0.973 , respectively, indicating that our regression models should not be biased by multicollinearity.

Table 2. Correlation matrix

Panel A: Correlation matrix ( $\beta$-risk model)

\begin{tabular}{|c|c|c|c|c|c|c|c|c|c|}
\hline & (1) & (2) & (3) & (4) & (5) & (6) & (7) & (8) & VIF \\
\hline (1) $\beta_{i, T}$ & 1.000 & & & & & & & & 0.979 \\
\hline (2) $\mathrm{AD}_{i, T-1}$ & $-0.130^{\mathrm{c}}$ & 1.000 & & & & & & & 1.035 \\
\hline (3) $\mathrm{RD}_{i, T-1}$ & $0.138^{c}$ & $0.093^{c}$ & 1.000 & & & & & & 1.353 \\
\hline (4) $\mathrm{G}_{i, T}$ & $0.073^{\mathrm{c}}$ & -0.024 & $0.061^{b}$ & 1.000 & & & & & 1.010 \\
\hline (5) Leverage L $_{i, T}$ & $0.058^{\mathrm{b}}$ & $-0.091^{\mathrm{c}}$ & $0.420^{c}$ & $0.069^{b}$ & 1.000 & & & & 1.251 \\
\hline (6) Liquidity $_{i, T}$ & $0.091^{\mathrm{c}}$ & $-0.065^{b}$ & $0.286^{\mathrm{c}}$ & $0.144^{\mathrm{c}}$ & $0.069^{b}$ & 1.000 & & & 0.907 \\
\hline (7) $\mathrm{TA}_{i, T}$ & -0.031 & $0.061^{b}$ & $0.133^{c}$ & $-0.139^{c}$ & $0.130^{\mathrm{c}}$ & $-0.399^{c}$ & 1.000 & & 0.279 \\
\hline (8) $\mathrm{HHI}_{i, t}$ & $0.074^{c}$ & $-0.125^{\mathrm{c}}$ & $0.072^{c}$ & -0.023 & $0.050^{\mathrm{a}}$ & $-0.099^{c}$ & $0.126^{\mathrm{c}}$ & 1.000 & 1.021 \\
\hline Ave. VIF & & & & & & & & & 0.980 \\
\hline
\end{tabular}

${ }^{8}$ The Jarque-Bera normality statistics are shown in the annotation for Panels A and B in Table 1. 
End of Table 2

Panel B: Correlation matrix (idiosyncratic risk model)

\begin{tabular}{|c|c|c|c|c|c|c|c|c|c|}
\hline & (1) & (2) & (3) & (4) & (5) & (6) & (7) & (8) & VIF \\
\hline (1) $\sigma_{i, T}^{2}$ & 1.000 & & & & & & & & 0.992 \\
\hline (2) $\mathrm{AD}_{i, T-1}$ & -0.039 & 1.000 & & & & & & & 1.034 \\
\hline (3) $\mathrm{RD}_{i, T-1}$ & $0.116^{\mathrm{c}}$ & $0.090^{\mathrm{c}}$ & 1.000 & & & & & & 1.347 \\
\hline (4) $\mathrm{G}_{i, T}$ & $0.067^{\mathrm{b}}$ & -0.029 & $0.065^{\mathrm{b}}$ & 1.000 & & & & & 1.004 \\
\hline (5) Leverage L $_{i, T}$ & 0.032 & $-0.094^{c}$ & $0.418^{\mathrm{c}}$ & $0.068^{b}$ & 1.000 & & & & 1.250 \\
\hline (6) Liquidity $_{i, T}$ & $0.162^{\mathrm{c}}$ & $-0.072^{\mathrm{c}}$ & $0.283^{c}$ & $0.136^{\mathrm{c}}$ & $0.069^{c}$ & 1.000 & & & 0.912 \\
\hline (7) $\mathrm{TA}_{i, T}$ & $-0.320^{c}$ & $0.075^{\mathrm{c}}$ & $0.128^{c}$ & $-0.130^{\mathrm{c}}$ & $0.130^{\mathrm{c}}$ & $-0.404^{\mathrm{c}}$ & 1.000 & & 0.229 \\
\hline (8) $\mathrm{HHI}_{i, t}$ & 0.032 & $-0.127^{c}$ & $0.078^{c}$ & -0.015 & $0.045^{\mathrm{a}}$ & $-0.095^{\mathrm{c}}$ & $0.104^{\mathrm{c}}$ & 1.000 & 1.017 \\
\hline Ave. VIF & & & & & & & & & 0.973 \\
\hline
\end{tabular}

Notes: ${ }^{\mathrm{a}} \mathrm{p}<0.10 ;{ }^{\mathrm{b}} \mathrm{p}<0.05 ;{ }^{\mathrm{c}} \mathrm{p}<0.01$. The VIF for the $j$ th regression coefficient can be presented as: $\mathrm{VIF}_{j}=1 /\left(1-R_{j}^{2}\right)$, where $R_{j}^{2}$ is the coefficient of multiple determination obtained from regressing $x_{j}$ on the other regressor variables

\section{Results}

\subsection{Results of OLS analysis}

In this section, this study firstly reports the OLS findings to view the central tendency profiles within our dataset. Panel A of Table 3 illustrates the results of the $\beta$-risk model using OLS. With respect to the $\beta$-risk model, we find that advertising is significantly associated with lower $\beta$-risk, consistent with McAlister et al. (2007), who use least square methods such as the fixed effect method. Concerning R\&D, our finding is consistent with Ho et al. (2004) and Berk et al. (2004), that the firm's R\&D is significantly associated with higher $\beta$-risk. That is, on average, a firm's $\beta$-risk could be reduced by advertising but increased by R\&D. Thus, Hypotheses 1 and 3 are supported.

On the other hand, as reported in Panel B of Table 3, on average, this study finds that advertising is not related to idiosyncratic risk, while R\&D is significantly associated with higher idiosyncratic risk. In summary, the OLS estimates show that, on average, a firm's advertising plays an important role in reducing the firm's $\beta$-risk but has no significant impact on idiosyncratic risk. However, R\&D is significantly associated with higher $\beta$-risk and idiosyncratic risk. For the other control variables, asset growth rate and competitive intensity are significantly associated with higher $\beta$-risk. That is, a firm's $\beta$-risk increases as asset growth rate and competitive intensity increase. Thus, Hypothesis 4 is supported but Hypothesis 2 is not supported. 
Table 3. Advertising, R\&D and risks: results of OLS

\begin{tabular}{|c|c|c|c|c|}
\hline \multirow{2}{*}{$\begin{array}{c}\text { Variables } \\
\text { Intercept }\end{array}$} & \multicolumn{2}{|c|}{ Panel A: $\beta$-risk model } & \multicolumn{2}{|c|}{ Panel B: Idiosyncratic risk mode } \\
\hline & 1.078 & $(0.000)^{\mathrm{c}}$ & 0.037 & $(0.000)^{\mathrm{c}}$ \\
\hline $\mathrm{AD}_{i, T-1}$ & -2.086 & $(0.000)^{\mathrm{c}}$ & -0.008 & $(0.411)$ \\
\hline $\mathrm{RD}_{i, T-1}$ & 1.629 & $(0.000)^{\mathrm{c}}$ & 0.043 & $(0.000)^{\mathrm{c}}$ \\
\hline $\mathrm{G}_{i, T}$ & 0.074 & $(0.040)^{b}$ & 0.000 & $(0.602)$ \\
\hline Leverage $_{i, T}$ & -0.003 & $(0.469)$ & 0.000 & $(0.821)$ \\
\hline Liquidity $_{i, T}$ & 0.012 & $(0.385)$ & -0.001 & $(0.367)$ \\
\hline $\mathrm{TA}_{i, T}$ & -0.011 & $(0.357)$ & -0.003 & $(0.000)^{\mathrm{c}}$ \\
\hline $\mathrm{HHI}_{i, t}$ & 0.501 & $(0.043)^{b}$ & 0.011 & $(0.049)^{\mathrm{b}}$ \\
\hline $\mathrm{R}^{2}\left(\right.$ adjusted $\left.\mathrm{R}^{2}\right)$ & 0.048 & $(0.043)$ & 0.132 & $(0.127)$ \\
\hline Observations & \multicolumn{2}{|c|}{1354} & \multicolumn{2}{|c|}{1396} \\
\hline$F($ d.f. $)$ & \multicolumn{2}{|c|}{9.7587} & \multicolumn{2}{|c|}{30.0231} \\
\hline
\end{tabular}

Notes: ${ }^{\mathrm{a}} \mathrm{p}<0.10 ;{ }^{\mathrm{b}} \mathrm{p}<0.05 ;{ }^{\mathrm{c}} \mathrm{p}<0.01$

As mentioned above, Barnes and Hughes (2002) argue that the estimates from OLS models conditional mean distribution may miss some important information. This leads us to question whether the determinants of firms with higher risk differ from those of firms with lower risk, that is, firms with different risk level may have different sensitives to advertising and R\&D expenditure. In the next section, this study further examines $\beta$-risk and idiosyncratic risk model, using the quantile regression to mitigate the estimated bias generated from a non-normally distributed sample and to understand the behavior of datapoints that are extremely high or low within a population.

\subsection{Results of quantile regression analysis}

\subsection{1. $\beta$-risk model}

The quantile regression analyses were carried out for quantile order $(\theta)$, where $\theta$ is from 0.1 though 0.9 . According to Panel A of Table 4, the $\beta$-risk model shows that advertising has significantly lower $\beta$-risk for firms with lower, median and higher $\beta$-risk, but has no significant effects on the extreme low- $\beta$-risk firms $(\theta=0.1)$. Our findings show that the slopes of the estimated quantiles increase with $\theta$, suggesting that firms more sensitive to market variations (the firms with higher $\beta$-risk) are sensitive to their advertising expenditure. In other words, advertising tends to have a stronger effect on the firms with higher $\beta$-risk than those with lower $\beta$-risk. Turning to $R \& D$, the coefficients for R\&D show significantly higher $\beta$-risk for firms with median and higher $\beta$-risk, but no significant effect for those with lower $\beta$-risk. We also find that the slopes of the estimated quantiles increase with the quantile order $\theta$. Our evidence shows that R\&D has a stronger effect on firms with higher $\beta$-risk than those with lower $\beta$-risk. 
Table 4. Advertising, R\&D and risks: results of quantile regression

Panel A: $\beta$-risk model

\begin{tabular}{lccccccccc}
\hline Variables & 0.1 & 0.2 & 0.3 & 0.4 & 0.5 & 0.6 & 0.7 & 0.8 & 0.9 \\
\hline Intercept & -0.012 & 0.152 & 0.322 & 0.615 & 0.832 & 1.061 & 1.334 & 1.840 & 2.559 \\
& $(0.945)$ & $(0.317)$ & $(0.016)^{\mathrm{b}}$ & $(0.000)^{\mathrm{c}}$ & $(0.000)^{\mathrm{c}}$ & $(0.000)^{\mathrm{c}}$ & $(0.000)^{\mathrm{c}}$ & $(0.000)^{\mathrm{c}}$ & $(0.000)^{\mathrm{c}}$ \\
\hline $\mathrm{AD}_{i, T-1}$ & -0.706 & -1.066 & -1.432 & -1.374 & -1.675 & -2.008 & -2.124 & -3.046 & -3.355 \\
& $(0.290)$ & $(0.065)^{\mathrm{a}}$ & $(0.005)^{\mathrm{c}}$ & $(0.003)^{\mathrm{c}}$ & $(0.000)^{\mathrm{c}}$ & $(0.000)^{\mathrm{c}}$ & $(0.000)^{\mathrm{c}}$ & $(0.000)^{\mathrm{c}}$ & $(0.000)^{\mathrm{c}}$ \\
\hline $\mathrm{RD}_{i, T-1}$ & -0.064 & -0.109 & 0.175 & 0.707 & 1.773 & 1.858 & 1.884 & 3.584 & 5.114 \\
& $(0.908)$ & $(0.819)$ & $(0.675)$ & $(0.061)^{\mathrm{a}}$ & $\left(0.000^{\mathrm{c}}\right.$ & $(0.000)^{\mathrm{c}}$ & $(0.000)^{\mathrm{c}}$ & $(0.000)^{\mathrm{c}}$ & $(0.000)^{\mathrm{c}}$ \\
\hline $\mathrm{G}_{i, T}$ & 0.048 & 0.047 & 0.082 & 0.129 & 0.155 & 0.146 & 0.113 & 0.124 & 0.062 \\
& $(0.394)$ & $(0.336)$ & $(0.056)^{\mathrm{a}}$ & $(0.001)^{\mathrm{c}}$ & $(0.000)^{\mathrm{c}}$ & $(0.000)^{\mathrm{c}}$ & $(0.004)^{\mathrm{c}}$ & $(0.009)^{\mathrm{c}}$ & $(0.300)$ \\
\hline Leverage $_{i, T}$ & -0.003 & -0.001 & -0.005 & -0.010 & -0.005 & -0.002 & 0.004 & -0.007 & -0.012 \\
& $(0.646)$ & $(0.844)$ & $(0.304)$ & $(0.032)^{\mathrm{a}}$ & $(0.287)$ & $(0.720)$ & $(0.346)$ & $(0.236)$ & $\left(0.0960^{\mathrm{a}}\right.$ \\
\hline Liquidity $_{i, T}$ & 0.037 & 0.039 & 0.036 & 0.024 & 0.019 & 0.025 & 0.043 & 0.008 & -0.033 \\
& $(0.093)^{\mathrm{a}}$ & $(0.043)^{\mathrm{b}}$ & $(0.034)^{\mathrm{b}}$ & $(0.112)$ & $(0.176)$ & $(0.088)^{\mathrm{a}}$ & $(0.006)^{\mathrm{c}}$ & $(0.685)$ & $(0.156)$ \\
\hline TA $_{i, T}$ & 0.033 & 0.042 & 0.045 & 0.024 & 0.005 & -0.008 & -0.033 & -0.057 & -0.105 \\
& $(0.093)^{\mathrm{a}}$ & $(0.014)^{\mathrm{b}}$ & $(0.002)^{\mathrm{c}}$ & $(0.076)^{\mathrm{a}}$ & $(0.688)$ & $(0.543)$ & $(0.015)^{\mathrm{b}}$ & $(0.001)^{\mathrm{c}}$ & $(0.000)^{\mathrm{c}}$ \\
\hline HHI $_{i, t}$ & 0.178 & -0.212 & -0.383 & -0.102 & 0.627 & 0.720 & 1.383 & 1.191 & 1.309 \\
& $(0.645)$ & $(0.527)$ & $(0.193)$ & $(0.700)$ & $(0.012)^{\mathrm{c}}$ & $(0.004)^{\mathrm{c}}$ & $(0.000)^{\mathrm{c}}$ & $(0.000)^{\mathrm{c}}$ & $(0.001)^{\mathrm{c}}$ \\
\hline
\end{tabular}

Panel B: Idiosyncratic risk model

\begin{tabular}{lccccccccc}
\hline Variables & 0.1 & 0.2 & 0.3 & 0.4 & 0.5 & 0.6 & 0.7 & 0.8 & 0.9 \\
\hline Intercept & 0.006 & 0.011 & 0.015 & 0.022 & 0.027 & 0.033 & 0.040 & 0.048 & 0.064 \\
& $(0.067)^{\mathrm{a}}$ & $(0.001)^{\mathrm{c}}$ & $(0.000)^{\mathrm{c}}$ & $(0.000)^{\mathrm{c}}$ & $(0.000)^{\mathrm{c}}$ & $(0.000)^{\mathrm{c}}$ & $(0.000)^{\mathrm{c}}$ & $(0.000)^{\mathrm{c}}$ & $(0.000)^{\mathrm{c}}$ \\
\hline $\mathrm{AD}_{i, T-1}$ & -0.002 & -0.001 & -0.006 & -0.011 & -0.016 & -0.021 & -0.022 & -0.023 & -0.031 \\
& $(0.871)$ & $(0.903)$ & $(0.573)$ & $(0.273)$ & $(0.107)$ & $(0.032)^{\mathrm{b}}$ & $(0.022)^{\mathrm{b}}$ & $(0.027)^{\mathrm{b}}$ & $(0.018)^{\mathrm{b}}$ \\
\hline $\mathrm{RD}_{i, T-1}$ & -0.004 & -0.001 & 0.010 & 0.023 & 0.033 & 0.044 & 0.058 & 0.078 & 0.097 \\
& $(0.726)$ & $(0.883)$ & $(0.254)$ & $\left(0.008^{\mathrm{c}}\right.$ & $(0.000)^{\mathrm{c}}$ & $(0.000)^{\mathrm{c}}$ & $(0.000)^{\mathrm{c}}$ & $(0.000)^{\mathrm{c}}$ & $(0.000)^{\mathrm{c}}$ \\
\hline $\mathrm{G}_{i, T}$ & 0.001 & 0.001 & 0.001 & 0.001 & 0.001 & 0.001 & 0.001 & 0.001 & 0.002 \\
& $(0.361)$ & $(0.304)$ & $(0.310)$ & $(0.435)$ & $(0.385)$ & $(0.197)$ & $(0.329)$ & $(0.174)$ & $(0.034)^{\mathrm{b}}$ \\
\hline Leverage $_{i, T}$ & 0.000 & 0.000 & -0.000 & -0.000 & -0.000 & 0.000 & -0.000 & -0.000 & -0.000 \\
& $(0.962)$ & $(0.796)$ & $(0.539)$ & $(0.170)$ & $(0.150)$ & $(0.632)$ & $(0.413)$ & $(0.095)^{\mathrm{a}}$ & $(0.053)^{\mathrm{a}}$ \\
\hline Liquidity $_{i, T}$ & 0.000 & 0.000 & 0.000 & 0.000 & -0.000 & -0.000 & -0.000 & -0.000 & -0.001 \\
& $(0.352)$ & $(0.435)$ & $(0.401)$ & $(0.942)$ & $(0.738)$ & $(0.502)$ & $(0.303)$ & $(0.239)$ & $(0.034)^{\mathrm{b}}$ \\
\hline TA $_{i, T}$ & -0.000 & -0.001 & -0.001 & -0.002 & -0.002 & -0.003 & -0.004 & -0.004 & -0.006 \\
& $(0.207)$ & $(0.006)^{\mathrm{c}}$ & $(0.000)^{\mathrm{c}}$ & $(0.000)^{\mathrm{c}}$ & $(0.000)^{\mathrm{c}}$ & $(0.000)^{\mathrm{c}}$ & $(0.000)^{\mathrm{c}}$ & $(0.000)^{\mathrm{c}}$ & $(0.000)^{\mathrm{c}}$ \\
\hline HHI $_{i, t}$ & 0.000 & 0.003 & 0.006 & 0.006 & 0.007 & 0.011 & 0.023 & 0.037 & 0.046 \\
& $(0.989)$ & $(0.609)$ & $(0.364)$ & $(0.323)$ & $(0.223)$ & $(0.059)^{\mathrm{a}}$ & $(0.000)^{\mathrm{c}}$ & $(0.000)^{\mathrm{c}}$ & $(0.000)^{\mathrm{c}}$ \\
\hline
\end{tabular}

Notes: Panel A and Panel B of this table presents quantile regressions of the $\beta$-risk and idiosyncratic risk, $\beta_{i, T}$ and $\sigma_{i, T}^{2}$, on measures of firm's risk. ${ }^{\mathrm{a}} \mathrm{p}<0.10$; ${ }^{\mathrm{b}} \mathrm{p}<0.05 ;{ }^{\mathrm{c}} \mathrm{p}<0.01$ 
For the control variables in $\beta$-risk model, we find that the coefficients of growth rate are significantly positive for firms with lower and higher $\beta$-risk while and are insignificant for those with extreme-low and extreme-high $\beta$-risk. With respect to liquidity, we find that liquidity ratio is related to firms with lower, median and higher $\beta$-risk. In terms of firm size and competitive intensity, we find that the coefficients of firm size for firms with lower $\beta$-risk are significantly positive, but significantly negative for firms with higher $\beta$-risk, and the coefficients of competitive intensity are only sensitive to firms with median and higher $\beta$-risk.

\subsubsection{Idiosyncratic risk model}

As shown in Panel B of Table 4, advertising is significantly associated with lower idiosyncratic risk for higher-idiosyncratic risk firms but no significant effects for firms with median and lower idiosyncratic risk. The evidence shows that advertising has stronger effect on firms with higher idiosyncratic risk than those with lower idiosyncratic risk. With regard to $R \& D, R \& D$ is significantly associated with higher idiosyncratic risk for firms with median and higher idiosyncratic risk firms, but no significant effect for those with lower idiosyncratic risk. The evidence shows that R\&D has stronger effect on firms with higher idiosyncratic risk than on those with lower idiosyncratic risk. Consistent with the finding in $\beta$-risk model, we also find that the slopes of the estimated quantiles increase with the quantile order $\theta$. Our evidence suggests that both advertising and R\&D tests resoundingly support Hypothesis 5, that the coefficients vary across the quantiles.

For control variables in the idiosyncratic-risk model, we find that the coefficients of asset growth rate and leverage are significantly positive for firms with extremely high idiosyncratic risk. With respective to liquidity, our evidence shows that liquidity is related to firms with lower and median idiosyncratic risk. In terms of asset size, the coefficients of asset size for firms with lower, median and higher idiosyncratic risk are significantly positive (except for firms with extremely low idiosyncratic risk). Finally, just as the results of the $\beta$-risk model, results show that the coefficients of competitive intensity are only sensitive to firms with median and higher idiosyncratic risk.

\subsubsection{Managerial implications}

The recent financial crisis has led to slumping property and stock prices, as well as a significant drop in the overall world economy, causing investors to consider their investment risk more closely. The issue of understanding the components of investment risk has thus received much attention in recent financial studies (Ang et al. 2006; Chang, Dong 2006; Janda, Svárovská 2010; Aktan et al. 2010; Banaitiené et al. 2011).

This paper employs quantile regression to investigate whether the changes in advertising and R\&D have different effects in response to firms with different risk levels. After decomposing a firm's total risk into $\beta$-risk and idiosyncratic risk, this study offers more detailed evidence to determine whether advertising and R\&D affect a firm's $\beta$-risk and idiosyncratic risk at the same time. Findings from the quantile analysis show a negative relationship between advertising and firm's idiosyncratic risk ( $\beta$-risk) only when firms are in the higher (higher and median-) idiosyncratic volatility ( $\beta$-risk) ranges. 
With respect to $R \& D$, this paper find a positive relationship between $R \& D$ and firm's idiosyncratic risk ( $\beta$-risk) only when firms are in the higher and median idiosyncratic risk ( $\beta$-risk) ranges. In other words, past research that uses OLS and similar methods considers only the central tendencies within a dataset and overlooks the more precise information close to the tails of a distribution. This finding is useful for senior management executives so they can more efficiently allocate limited resources such advertising.

Lui et al. (2007) indicate that financial analysts tend to use idiosyncratic risk to rate a firm's risk when issuing their investment report. Ang et al. (2006) show evidence that idiosyncratic risk is associated with lower individual stock returns. Clayton et al. (2005) show that higher idiosyncratic risk can put the survival of a firm at risk, hamper efforts to acquire or divest firm stock (stock market liquidity), and affect the value of stock options. The value of stock options and stock prices may have a reciprocal influence. Stockholders may be exerting their influence on firm's senior executives to spend more on advertising or less on R\&D when their investments are in firms with higher idiosyncratic risk.

\section{Conclusions}

From a marketing perspective, managers frequently focus on customers or product markets as the ultimate objective. In contrast, financial managers focus on the capital market. There is, however, a recent trend in the marketing literature indicating a shift in evaluating the impact of marketing strategies on improving stock market returns (Srivastava et al. 1998; Joshi, Hanssens 2004; Singh et al. 2005; Fornell et al. 2006; Madden et al. 2006; McAlister et al. 2007). This newer view finds that firms with higher intangible market-based assets have higher stock returns and lower stock return risk than their competitors.

In this study we show that quantile regression analysis provides new insights to this area of research and suggests that there may be differential advertising and R\&D effects at different points in the conditional distributions of a firm's $\beta$-risk and idiosyncratic-risk. Prior studies have shown that the distribution of the firm's risk is non-normal. Therefore, using a least squares model without concern for whether the sample is based on the assumption of Gaussian distributed error terms would not be efficient and may lead to unreliable estimates. Quantile regression is not limited to explaining the mean or median of the dependent variable, but it does allow an estimation of response to coefficients across a wide spectrum of the distribution of dependent variable and can minimize estimated bias generated from skewed and non-normal samples.

With regard to $\beta$-risk, we find that advertising is significantly associated with lower $\beta$-risk for firms with lower, median and higher $\beta$-risk, but has no significant effects on those with extremely low $\beta$-risk. Our evidence shows that the slopes of the estimated quantiles increase with $\theta$. These findings suggest that firms which are more sensitive to capital market variations (higher- $\beta$-risk firms), are also sensitive to their advertising expenditures. In other words, advertising tends to have stronger effect on higher- $\beta$-risk firms than on lower- $\beta$-risk firms. On the other hand, R\&D is significantly associated 
with higher $\beta$-risk for firms with median and higher $\beta$-risk, with no significant effect for those with lower $\beta$-risk. We also find that the slopes of the estimated quantiles increase with the quantile order. Our evidence shows that R\&D has a stronger effect on firms with higher $\beta$-risk than those with lower $\beta$-risk. For firms' idiosyncratic risk, this study finds that advertising is significantly associated with lower idiosyncratic risk for firms with higher idiosyncratic risk but has no significant effects for those with median and lower idiosyncratic risk. This indicates that advertising has a stronger effect on higheridiosyncratic risk firms than on lower-idiosyncratic risk firms. R\&D is significantly associated with higher idiosyncratic risk for firms with median and higher idiosyncratic risk, and has insignificant effect on firms with lower idiosyncratic risk. This indicates that $R \& D$ has a stronger effect on firms with higher idiosyncratic risk than on those with lower idiosyncratic risk. Consistent with findings for the $\beta$-risk model, we also find that the slopes of the estimated quantiles increase with the quantile order, suggesting that advertising and R\&D tests resoundingly support our hypothesis that the coefficients vary across the quantiles. Our findings are useful for management executives and investors. For firm managers, the findings can help them allocate limited resources more efficiently to reduce their firm's risk. Investors and shareholders could press the management executives in the firms in which they have invested to make decisions that are beneficial to their investment returns.

\section{References}

Adegbesan, J. A.; Higgins, M. J. 2010. The intra-alliance division of value created through collaboration, Strategic Management Journal 32(2): 187-211. http://dx.doi.org/10.1002/smj.872

Aktan, B.; Korsakienè, R.; Smaliukienè, R. 2010. Time-varying volatility modeling of Baltic stock markets, Journal of Business Economics and Management 11(3): 511-532.

http://dx.doi.org/10.3846/jbem.2010.25

Ang, A.; Hokrick, R. J.; Xing, Y.; Zhang, X. 2006. The cross-section of volatility and expected returns, Journal of Finance 61(1): 259-299. http://dx.doi.org/10.1111/j.1540-6261.2006.00836.x Austin, D. H. 1993. An event-study approach to measuring innovative output: the case of biotechnology, American Economic Review 83(2): 253-258.

Ball, R.; Kothari, S. P.; Shanken, J. 1995. Problems in measuring portfolio performance: an application to contrarian investment strategies, Journal of Financial Economics 38(1): 79-107. http://dx.doi.org/10.1016/0304-405X(94)00806-C

Banaitienè, N.; Banaitis, A.; Norkus, A. 2011. Risk management in projects: peculiarities of Lithuanian construction companies, International Journal of Strategic Property Management 15(1): 60-73. http://dx.doi.org/10.3846/1648715X.2011.568675

Barnes, M. L.; Hughes, A. W. 2002. A quantile regression analysis of the cross section of stock market returns. Available from Internet: http://www.bos.frb.org (Federal Reserve Bank of Boston, USA).

Beaver, W.; Kettler, P.; Scholes, M. 1970. The association between market-determined and accounting-determined risk measures, The Accounting Review 45(4): 654-682.

Berk, J.; Green, R. C.; Naik, V. 2004. The valuation and return dynamics of new ventures, Review of Financial Studies 17(1): 1-35. http://dx.doi.org/10.1093/rfs/hhg021

Boudoukh, J.; Richardson, M.; Whitelaw, R. F. 1994. Industry returns and the Fisher effect, Journal of Finance 49(5): 1595-1615. 
Bublitz, B.; Ettredge, M. 1989. The information in discretionary outlays: advertising, research and development, The Accounting Review 64(1): 108-124.

Chambers, D.; Jennings, R.; Thompson, R. B. 2002. Excess returns to R\&D intensive firms, Review of Accounting Studies 7(2-3): 133-158. http://dx.doi.org/10.1023/A:1020217817156

Chan, L. K. C.; Lakonishok, J.; Sougiannis, T. 2001. The stock market valuation of research and development expenditures, Journal of Finance 56(6): 2431-2456.

http://dx.doi.org/10.1111/0022-1082.00411

Chang, E. C.; Dong, S. 2006. Idiosyncratic volatility, fundamentals, and institutional herding: evidence from the Japanese stock market, Pacific-Basin Finance Journal 14(2): 135-154.

http://dx.doi.org/10.1016/j.pacfin.2005.09.001

Chen, J. 2002. Intertemporal, CAPM and the cross-section of stock returns, Working paper. University of Southern California.

Chen, M. C.; Peng, C. L.; Shyu, S. D.; Zeng, J. H. 2010. Market states and the effect on equity REIT returns due to changes in monetary policy stance, Journal of Real Estate Finance and Economics (forthcoming). http://dx.doi.org/10.1007/s11146-010-9264-1

Clayton, M. C.; Hartzell, J. C.; Rosenberg, J. 2005. The impact of CEO turnover on equity volatility, Journal of Business 78(5): 1779-1808. http://dx.doi.org/10.1086/431442

Coad, A.; Rao, R. 2006. Innovation and market value: a quantile regression analysis, Economics Bulletin 15(13): 1-10.

Cooper, M. J.; Gutierrez, R. C.; Hameed, A. 2004. Market states and momentum, Journal of Finance 59(3): 1345-1365. http://dx.doi.org/10.1111/j.1540-6261.2004.00665.x

Dzikevičius, A. 2005. Risk adjustment and performance measurement: symmetrical versus asymmetrical measures, Verslas: teorija ir praktika [Business: Theory and Practice] 6(2): 77-84.

Fama, E. F.; MacBeth, J. D. 1973. Risk, return, and equilibrium: empirical tests, Journal of Political Economy 81(3): 607-636. http://dx.doi.org/10.1086/260061

Fattouh, B.; Scaramozzino, P.; Harris, L. 2005. Capital structure in South Korea: a quantile regression approach, Journal of Development Economics 76(1): 231-250.

http://dx.doi.org/10.1016/j.jdeveco.2003.12.014

Fornell, C.; Mithas, S.; Morgeson, F. V.; Krishnan, M. S. 2006. Customer satisfaction and stock prices: high returns, low risk, Journal of Marketing 70(1): 3-14.

http://dx.doi.org/10.1509/jmkg.2006.70.1.3

Frieder, L.; Subrahmanyam, A. 2005. Brand perceptions and the market for common stock, Journal of Financial and Quantitative Analysis 40(1): 57-85.

http://dx.doi.org/10.1017/S0022109000001745

Goetzmann, W. N.; Peles, N. 1997. Cognitive dissonance and mutual fund investors, Journal of Financial Research 20(2): 145-158.

Griliches, Z. 1987. R\&D, Patents, and Productivity. University of Chicago Press. Chicago.

Grullon, G.; Kanatas, G.; Weston, J. P. 2004. Advertising, breadth of ownership and liquidity, Review of Financial Studies 17(2): 439-461. http://dx.doi.org/10.1093/rfs/hhg039

Gupta, A.; Liang, B. 2005. Do hedge funds have enough capital? A value-at-risk approach, Journal of Financial Economics 77(1): 219-253. http://dx.doi.org/10.1016/j.jfineco.2004.06.005

Hertzel, M.; Lemmon, M.; Linck, J. S.; Rees, L. 2002. Long-run performance following private placements of equity, Journal of Finance 57(6): 2595-2617.

http://dx.doi.org/10.1111/1540-6261.00507

Ho, Y. K.; Xu, Z.; Yap, C. M. 2004. R\&D investment and systematic risk, Accounting and Finance 44(3): 393-418. http://dx.doi.org/10.1111/j.1467-629x.2004.00116.x

Jaffe, A. B. 1986. Technological opportunity and spillovers of R\&D: evidence from firms' patents, profits, and market value, American Economic Review 76(5): 984-1001. 
Janda, K.; Svárovská, B. 2010. Investing in to microfinance, Journal of Business Economics and Management 11(3): 483-510.

Jorion, P. 1991. The pricing of exchange rate risk in the stock market, Journal of Financial and Quantitative Analysis 26(3): 363-376. http://dx.doi.org/10.2307/2331212

Joshi, A.; Hanssens, D. M. 2004. Advertising spending and market capitalization. Available from Internet: http://www.msi.org/publications/publication.cfm?pub=710. Marketing Studies Center. Anderson School of Management, University of California, Los Angeles.

Koenker, R. 2000. Galton, Edgeworth, Frisch, and prospects for quantile regression in econometrics, Journal of Econometrics 95(2): 347-374. http://dx.doi.org/10.1016/S0304-4076(99)00043-3

Koenker, R.; Bassett, G. 1978. Regression quantiles, Econometrica 46(1): 33-50.

http://dx.doi.org/10.2307/1913643

Koenker, R.; Hallock, K. F. 2001. Regression quantiles, Journal of Economic Perspective 15(4): 143-156. http://dx.doi.org/10.1257/jep.15.4.143

Kothari, S. P.; Laguerre, T. E.; Leone, A. J. 2002. Capitalization versus expensing: evidence on the uncertainty of future earnings from capital expenditures versus R\&D outlays, Review of Accounting Studies 7(4): 355-382. http://dx.doi.org/10.1023/A:1020764227390

Krasnikov, A.; Jayachandran, S. 2008. The relative impact of marketing, research-and-development, and operations capabilities on firm performance, Journal of Marketing 72(4): 1-11.

http://dx.doi.org/10.1509/jmkg.72.4.1

Landajo, M.; de Andrés, J.; Lorca, P. 2008. Measuring firm performance by using linear and non-parametric quantile regressions, Journal of the Royal Statistical Society: Series C (Applied Statistics) 57(2): 227-250. http://dx.doi.org/10.1111/j.1467-9876.2007.00610.x

Lee, J. S. 2008. The determinants of IPO underpricing: application of quantile regression, Review of Securities and Futures Markets 20(1): 47-99.

Lev, B.; Sougiannis, T. 1996. The capitalization, amortization, and value-relevance of R\&D, Journal of Accounting and Economics 21(1): 107-138.

http://dx.doi.org/10.1016/0165-4101(95)00410-6

Lind, D. A.; Marchal, W. G.; Wathen, S. A. 2004. Statistical Techniques in Business and Economics. McGraw-Hill/Irwin.

Lintner, J. 1965. The valuation of risky assets and the selection of risky investment in stock portfolios and capital budgets, Review of Economics and Statistics 47(1): 13-37.

http://dx.doi.org/10.2307/1924119

Lui, D.; Markov, S.; Tamayo, A. 2007. What makes a stock risky? Evidence from sell-side analysts' risk ratings, Journal of Accounting Research 45(3): 629-665.

http://dx.doi.org/10.1111/j.1475-679X.2007.00242.x

Madden, T. J.; Fehle, F.; Fournier, S. 2006. Brands matter: an empirical demonstration of the creation of shareholder value through branding, Journal of the Academy of Marketing Science 34(2): 224-235. http://dx.doi.org/10.1177/0092070305283356

McAlister, L.; Srinivasan, R.; Kim, M. C. 2007. Advertising, research and development, and systematic risk of the firm, Journal of Marketing 71(1): 35-48.

http://dx.doi.org/10.1509/jmkg.71.1.35

McCue, T. E.; Kling, J. L. 1994. Real estate returns and the macroeconomy: some empirical evidence from real estate investment trust data, 1972-1991, Journal of Real Estate Research 9(3): 5-32.

Meligkotsidou, L.; Vrontos, I. D.; Vrontos, S. D. 2009. Quantile regression analysis of hedge fund strategies, Journal of Empirical Finance 16(2): 264-279.

http://dx.doi.org/10.1016/j.jempfin.2008.10.002 
Mizik, N.; Jacobson, R. 2003. Trading off between value creation and value appropriation: the financial implication of shifts in strategic emphasis, Journal of Marketing 67(1): 63-76. http://dx.doi.org/10.1509/jmkg.67.1.63.18595

Montgomery, D. C.; Peck, E. A.; Vining, C. C. 2001. Introduction to Linear Regression Analysis. 3th ed. John Wiley and Sons, New York, NY.

Moskowitz, T. J.; Grinblatt, M. 1999. Do industries explain momentum?, Journal of Finance 54(4): 1249-1290. http://dx.doi.org/10.1111/0022-1082.00146

Mossin, J. 1966. Equilibrium in a capital asset market, Econometrica 34(4): 768-783.

http://dx.doi.org/10.2307/1910098

Patton, A. J. 2009. Are "Market Neutral" hedge funds really market neutral, Review of Financial Studies 22(7): 2495-2530. http://dx.doi.org/10.1093/rfs/hhn113

Roberts, P. W. 2001. Innovation and firm-level persistent profitability: a Schumpeterian framework, Managerial and Decision Economics 22(4-5): 239-250.

http://dx.doi.org/10.1002/mde.1018

Roll, R. 1977. A critique of the asset pricing theory's tests part I: on past and potential testability of the theory, Journal of Financial Economics 4(2): 129-176.

http://dx.doi.org/10.1016/0304-405X(77)90009-5

Roll, R.; Ross, S. A. 1994. On the cross-sectional relation between expected returns and betas, Journal of Finance 49(1): 101-121.

Rosenberg, B. 1974. Extra-market components of covariance in security returns, Journal of Financial Quantitative Analysis 9(2): 263-274. http://dx.doi.org/10.2307/2330104

Santa-Clara, P.; Valkanov, R. 2003. The presidential puzzle: political cycles and the stock market, Journal of Finance 58(5): 1841-1872. http://dx.doi.org/10.1111/1540-6261.00590

Sharpe, W. F. 1964. Capital asset prices: a theory of market equilibrium under conditions of risk, Journal of Finance 19(3): 425-442.

Shimizu, K.; Hitt, M. A. 2005. What constrains or facilitates divestitures of formerly acquired firms? The effects of organizational inertia, Journal of Management 31(1): 50-72.

http://dx.doi.org/10.1177/0149206304271381

Singh, M.; Faircloth, S.; Nejadmalayeri, A. 2005. Capital market impact of product marketing strategy: evidence from the relationship between advertising expenses and cost of capital, Journal of the Academy of Marketing Science 33(4): 432-444. http://dx.doi.org/10.1177/0092070305277380

Srivastava, R. K.; Shervani, T. A.; Fahey, L. 1998. Market-based assets and shareholder value: a framework for analysis, Journal of Marketing 62(1): 2-18. http://dx.doi.org/10.2307/1251799

Tuli, K. R.; Bharadwaj, S. G. 2009. Customer satisfaction and stock returns risk, Journal of Marketing 73(6): 184-197. http://dx.doi.org/10.1509/jmkg.73.6.184

Viscusi, W. K.; Born, P. H. 2005. Damages caps, insurability, and the performance of medical malpractice insurance, Journal of Risk and Insurance 72(1): 23-43.

http://dx.doi.org/10.1111/j.0022-4367.2005.00114.x

Woolridge, J. R. 1988. Competitive decline and corporate restructuring: is a myopic stock market to blame?, Journal of Applied Corporate Finance 1(1): 26-36.

http://dx.doi.org/10.1111/j.1745-6622.1988.tb00155.x

$\mathrm{Xu}, \mathrm{M}$; Zhang, C. 2004. The explanatory power of R\&D for the cross-section of stock returns: Japan 1985-2000, Pacific-Basin Finance Journal 12(3): 245-269.

http://dx.doi.org/10.1016/j.pacfin.2003.09.001

Zietz, J.; Zietz, E. N.; Sirmans, G. S. 2008. Determinants of house prices: a quantile regression approach, Journal of Real Estate Finance and Economics 38(4): 66-75. 
Miao-Ling CHEN is a professor in the Department of Finance, National Sun Yat-sen University, Taiwan. She received her Ph.D. degree in Business from Keio University in Japan. She teaches both undergraduate and graduate courses, including Accounting, Financial Statement Analysis, Financial Marketing, and others. Her research include: management accounting research, consumer behavior, investment and advertising. She has published in refereed journals such as the Journal of Business Research, Investment Analysts Journal, Journal of Management, Applied Economics, Applied Economics Letters, Journal of Chinese Economic and Business Studies and Fair Trade Quarterly.

Chi-Lu PENG is an assistant professor in the Department of Finance, Chung Hua University, Taiwan. He received his Ph.D. degree in Finance from National Sun Yat-sen University, Taiwan. His current research interests include issue related to financial economics, portfolio management, real estate finance and financial marketing. One of his professional specialties is structural change using quantile regression. His recent academic papers have been published in refereed journals such as the Journal of Real Estate Finance and Economics, Investment Analysts Journal, Journal of Management, International Research Journal of Finance and Economics, and Pan-Pacific Management Review.

An-Pin WEI received his Ph.D. degree in Finance from National Sun Yat-sen University, Taiwan. His current research interests include issue related to financial economics, portfolio management, investment, securities pricing and financial marketing. He has a professional specialty on structural change using non-linear regressions. His recent academic papers have been published in refereed journals such as the Investment Analysts Journal, and Journal of Management. 